\title{
Pemanfaatan Dedak Padi dan Jerami Fermentasi pada Usaha Penggemukan Sapi Potong di Jawa Barat
}

\author{
Using Rice Bran and Fermented Rice Straw for Fattening Beef Cattle in West Java
}

\author{
S.L. Mulijanti, S. Tedy, Nurnayetti \\ Balai Pengkajian Teknologi Pertanian Jawa Barat \\ Jl. Kayu Ambon No. 80 Lembang \\ E-Mail : liamulijanti@yahoo.com \\ (Diterima : 13 Agustus 2014, Disetujui : 3 Juni 2014)
}

\begin{abstract}
ABSTRAK
Penelitian ini bertujuan untuk mengetahui tingkat penggunaan pakan dari limbah padi terhadap pertambahan bobot badan dan nilai ekonomi usaha ternak sapi potong. Penelitian ini dilaksanakan pada bulan Juli - Desember 2011 di kelompok ternak Metal Sangkan Hurip Desa Sukajaya Kecamatan Sumedang Selatan Kabupaten Sumedang. Rancangan percobaan yang digunakan adalah Rancangan Acak Kelompok (RAK) dengan 4 perlakuan dan 8 ulangan, dengan perlakuan sebagai berikut: A (jerami segar+konsentrat komersil), B (jerami segar+dedak padi), C (jerami fermentasi+konsentrat komersil), D (jerami fermentasi+dedak padi). Untuk mengetahui perlakuan pemberian pakan yang paling ekonomis dilakukan uji analisis losses and gain dengan membandingkan perlakukan A dengan perlakuan B, C dan D yang diperoleh dari nilai marginal benefit cost ratio (MBCR). Hasil pengkajian menunjukkan bahwa rata-rata PPBH ternak yang diberi perlakuan jerami fermentasi+dedak padi hasilnya lebih tinggi yaitu sebesar $0,78 \mathrm{~kg}$, jerami segar+dedak padi $0,70 \mathrm{~kg}$, jerami fermentasi+konsentrat komersial $0,67 \mathrm{~kg}$ dan jerami segar+konsentrat komersial $0,55 \mathrm{~kg}$. Sedangkan dari hasil analisa imbangan pendapatan atas biaya (B/C) 1,41 diperoleh hasil inovasi teknologi pakan jerami fermentasi+dedak padi, 1,37 untuk jerami segar+dedak padi, nilai yang sama dengan perlakuan jerami fermentasi+konsentrat komersil, dan 1,25 untuk jerami segar+konsentrat komersil. Pemanfaatan jerami fermentasi dan dedak padi memberikan pertambahan bobot badan tertinggi dan secara ekonomi memberikan keuntungan tertinggi.
\end{abstract}

Kata Kunci : jerami fermentasi, dedak padi, sapi potong, pertambahan berat badan harian

\begin{abstract}
The study aimed at understanding the effect of using rice straw on body weight gained and economic value of beef cattle business. Study was conducted in July-December 2011 at the Metal Sangkan Hurip farmer group at Sukajaya Village, South Sumedang, in Sumedang District. A randomized group design was applied with 4 treatments and 8 replications for 32 PO cattle consisting of following treatment category; A (fresh straw with commercial concentrates), B (fresh straw with rice bran), $C$ (fermented straw with the addition of commercial concentrates), and $D$ (fermented straw with rice bran). To know the treatments that had economic value was used loss and gain analysis from MBCR value of each treatments. The results showed that average daily gain of beef cattle treated by fermented rice straw + rice bran was the highest at $0.78 \mathrm{~kg}$; fresh rice straw+rice bran was $0.70 \mathrm{~kg}$; fermented rice straw+commercial concentrate was $0.67 \mathrm{~kg}$ and fresh rice straw + commercial concentrate was $0.55 \mathrm{~kg}$. B/C ratio analysis showed a number of 1.41 for (fermented rice straw+rice bran); 1,37 for (fresh rice straw+ rice bran) and (fermented rice straw+commercial concentrate) and 1,25 for (fresh rice straw+commercial concentrate). Fermented straw with rice bran was the best feed for the beef cattle.
\end{abstract}

Keywords : fermented rice straw, rice bran, beef cattle, average daily gain 


\section{PENDAHULUAN}

Usaha penggemukan ternak di Jawa Barat dilakukan dengan 2 pola pemeliharaan, yaitu sistem kereman dan diangon. Pemeliharaan ternak sistem kereman umumnya dilakukan karena keterbatasan lahan dan kurangnya lahan pengangonan sehingga pemberian pakan rumput lapang dengan cara cut and carry. Kondisi ini memerlukan ketersediaan hijauan pakan yang umumnya terkendala terutama pada musim kemarau. Oleh karena itu peternak sering memanfaatkan limbah pertanian yang umumnya tersedia sepanjang tahun. Ketersediaan jerami padi sepanjang tahun telah dimanfaatkan peternak sebagai sumber pakan, tanpa melihat kualitas jerami yang sebagian besar terdiri atas serat kasar dan rendah protein.

Ketersediaan jerami padi dan dedak padi tersedia hampir sepanjang tahun sehingga dapat digunakan sebagai sumber pakan ternak, khususnya pada musim kemarau. Untuk menyediakan pakan ternak secara kontinyu, diperlukan suatu teknologi pengawetan sehingga pada saat bahan pakan melimpah dapat disimpan tanpa mengurangi kandungan nutriennya. Salah satu bentuk pengawetan yang sesuai dengan karakteristik jerami padi adalah dengan pembuatan fermentasi jerami, karena proses pembuatannya relatif mudah serta bersifat palatable sehingga lebih mudah pemberiannya untuk ternak ruminansia.

Fermentasi jerami perlu dilakukan untuk meningkatkan nilai gizinya. Jerami fermentasi dapat meningkatkan kandungan protein kasar sebesar 4,88\% dari 4,01\% menjadi 9,09\%, serta menurunkan serat kasar $6,32 \%$ dari $24,76 \%$ menjadi 18,44\% (Basuni et al,. 2010). Proses fermentasi jerami padi dilakukan guna peningkatan nilai nutrisinya,menyebabkan disukai ternak (Syamsu, 2006). Peningkatan protein dan penurunan serat kasar jerami fermentasi sangat mendukung dalam pemanfaatannya sebagai pakan ternak, karena umumnya yang menjadi pembatas dalam pemanfaatan limbah pertanian sebagai pakan ternak adalah rendahnya kandungan nutrien dan tingginya serat kasar.
Hal-hal yang berkaitan dengan pemberian pakan ternak adalah kebutuhan nutrisi ternak, komposisi nutrisi bahan pakan penyusun ransum dan bagaimana beberapa bahan dapat dikombinasikan (penyusunan ransum standar) untuk mencukupi kebutuhan ternak (Subandriyo et al., 2000). Kualitas dedak padi sebagai sumber pakan mempunyai tingkat protein cukup tinggi, hanya penggunaanya belum maksimal karena keterbatasan pengetahuan dan modal.

Berkaitan dengan berbagai permasalahan tersebut maka pemanfaatan bahan pakan lokal perlu dioptimalkan sehingga dapat menekan biaya pakan tanpa mengganggu produktivitas ternak. Salah satu upaya yang dapat ditempuh adalah memelihara ternak secara terintegrasi dengan tanaman pangan. Dengan upaya tersebut diharapkan keterbatasan pakan yang selama ini menjadi faktor pembatas dapat diatasi dengan memanfaatkan limbah pertanian, antara lain jerami padi dan dedak padi sehingga produktivitas tanaman pangan dan ternak menjadi lebih baik (Kariyasa 2005; Gordeyase et al. 2006; Suryana 2007). Hambatan lain yang sering ditemui dalam penerapan model ini diantaranya adalah penggunaan limbah pertanian untuk pakan belum optimal karena umumnya petani belum mengetahui teknologi pemanfaatannya secara baik dan benar sesuai kebutuhan gizi ternak.

Jawa Barat dengan luas panen padi sawah 5 juta Ha dan 11 ribu Ha padi ladang (BPS, 2012), mampu menyediakan sekitar 7,5 juta ton jerami padi dan 81 ribu ton dedak padi. Ini merupakan potensi yang besar sebagai penyedia pakan ternak khususunya sapi potong. Oleh karena itu perlu dilakukan kajian penggunaan jerami padi dan dedak padi sebagai pakan sapi potong guna menghasilkan inovasi teknologi pakan yang cocok untuk kondisi petani. Tujuan pengkajian ini untuk mengetahui tingkat pertambahan bobot badan sapi potong dan nilai ekonomi usahaternak dengan penggunaan pakan dari dedak dan jerami fermentasi. 


\section{METODE}

\section{Rancangan Pengkajian}

Pengkajian ini dilakukan di kelompok ternak Metal Sangkan Hurip, Desa Sukajaya, Kecamatan Sumedang Selatan, Kabupaten Sumedang, Provinsi Jawa Barat dari bulan JuniSeptember tahun 2011. Sebanyak 32 ekor Sapi jantan Peranakan Ongol berumur antara 1218 bulan yang dipelihara 13 peternak dibagi dalam 4 kelompok dengan perlakuan sebagai berikut: A (Perlakuan jerami segar dengan tambahan konsentrat komersil), B (Perlakuan jerami segar dengan tambahan dedak padi, C (Perlakuan jerami fermentasi dengan tambahan konsentrat komersil), D (Perlakuan jerami fermentasi dengan tambahan dedak padi).

Rancangan percobaan yang digunakan pada penelitian ini adalah Rancangan Acak Kelompok (RAK) dengan 4 perlakuan dan 8 ulangan. Analisis data untuk percobaan ini menggunakan ANOVA (sidik ragam) dan jika berbeda nyata akan diuji dengan uji jarak Duncan.

\section{Pembuatan Jerami Fermentasi}

Bahan pembuatan jerami fermentasi terdiri atas $2,5 \mathrm{~kg}$ probiotik dan $0,25 \mathrm{~kg}$ urea dicampur sebagai bahan fermentasi. Sebanyak $100 \mathrm{~kg}$ jerami kadar air $10 \%$ ditebar seluas $3 \times 3$ meter disusun setebal $50 \mathrm{~cm}$ kemudian ditaburi dengan 3 genggam probiotok, kemudian disusun jerami setebal $50 \mathrm{~cm}$ dan ditaburi probiotik kembali hingga seluruh jerami habis. Tutup permukaan susunan jerami dengan terpal plastik dan biarkan selama 3 minggu. Setelah 3 minggu jerami fermentasi siap dipanen, dengan membuka tutup terpal kemudian angin-anginkan jerami fermentasi untuk menghilangkan uap sisa proses fermentasi. Sebelum diberikan kepada ternak jerami fermentasi dicacah terlebih dahulu untuk meningkatkan palatabilitas dan memudahkan dalam mengkonsumsi jerami, setelah dicacah jerami kemudian dimasukkan ke dalam karung sehingga mudah untuk disimpan.

\section{Cara Pemberian Pakan}

Pemberian pakan dilakukan sehari 2

kali, pada pagi hari diberi konsentrat atau dedak padi, sedangkan jerami fermentasi atau jerami segar sebanyak 8-9 kg/ekor/hari diberikan 2 kali pagi dan sore. Pemberian konsentrat atau dedak 2-3 kg/ekor/hari dilakukan pagi hari 2 jam sebelum pemberian jerami fermentasi, hal ini sesuai pendapat (Siregar, 1996) yang mengatakan bahwa pemberian konsentrat 2 jam sebelum pemberian jerami, akan meningkatkan kecernaan bahan kering dan bahan organik ransum.

\section{Parameter Yang diukur}

1) Konsumsi

Tingkat konsumsi pakan dinyatakan dalam persentase terhadap jumlah pakan yang dikonsumsi dibandingkan dengan sisa pakan. Pengamatan konsumsi dengan cara menimbang jumlah pakan yang diberikan yaitu pagi dan sore hari, kemudian menimbang sisa pakan pada keesokan harinya. Pengukuran konsumsi ini pakan berdasarkan konsumsi bahan kering (BK), yaitu selisih antara BK yang diberikan dengan BK sisa. Pengukuran BK diperoleh dari 100\% dikurangi kadar air bahan pakan. Pengukuran Kadar Air dilakukan di Laboratorium Pasca Panen BPTP Jawa Barat. Konsumsi Nutrien (Protein dan Total Digestible Nutirent/TDN) diperoleh dengan mengalikan konsumsi BK dengan kandungan nurtrien pakan.

Rumus perhitungan konsumsi pakan adalah sebagai berikut :

Konsumsi Pakan BK :

BK pemberian $(\mathrm{kg})$ - BK sisa $(\mathrm{kg})$

Konsumsi Protein Kasar (kg) :

Konsumsi BK x \% Kandungan Protein Pakan

Konsumsi TDN (kg) :

Konsumsi BK x \% Kandungan TDN Pakan

2) Pertambahan Bobot Badan Harian (PB$\mathrm{BH})$

Sebelum dilakukan perlakuan, sapi dibiasakan dengan kondisi pakan perlakuan selama adaptasi 1 minggu, kemudian sapi diukur berat badannya pada minggu ke 3 dan diulang setiap 2 minggu selama 3 bulan. Respon pertumbuhan ternak pada setiap kelompok diukur dengan : 


$$
\text { PBBH }(\mathrm{kg})=\frac{\text { Bobot Akhir Pengamatan }(\mathrm{kg})-\text { Bobot Awal Pengamatan }(\mathrm{kg})}{\text { Lama pengamatan (hari) }}
$$

melakukan penimbangan berat badan ternak menggunakan lingkar badan dengan pita ukur ternak (Scroll) dilakukan setiap 2 minggu. Pertambahan bobot badan dihitung dengan rumus sebagai berikut:

\section{Kelayakan Usahaternak}

Kelayakan usahaternak dihitung berdasarkan output usahaternak yaitu nilai ekonomis dari pertambahan bobot badan harian $(\mathrm{PBBH})$, yaitu dengan mengalikan nilai pertambahan bobot badan harian ternak dengan nilai ekonomis yaitu harga jual berat hidup ternak per $\mathrm{kg}$. Sehingga diperoleh harga output usahaternak selama periode penggemukan (90 hari). Output Usahaternak (Rp) $=\mathrm{PBBH}(\mathrm{kg} / \mathrm{hr}) \times(\mathrm{Rp} / \mathrm{kg})$.

Untuk mengetahui perlakuan yang paling menguntungkan dibandingkan perlakukan petani (perlakuan A), digunakan analisis Losses and Gain yang diperoleh dari nilai marginal benefit cost ratio (MBCR). Tahapan perhitungan terhadap masing-masing perlakuan adalah :

1. Membandingkan hasil perlakuan A dan B

$$
\operatorname{MBCR}(A-B)=\frac{\pi_{B}-\pi_{A}}{C_{B}-C_{A}}
$$

2. Membandingkan hasil perlakuan $\mathrm{A}$ dan $\mathrm{C}$

$$
M B C R(A-C)=\frac{\pi_{C}-\pi_{A}}{C_{C}-C_{A}}
$$

3. Membandingkan hasil perlakuan A dan D

$$
M B C R(A-D)=\frac{\pi_{D}-\pi_{A}}{C_{D}-C_{A}}
$$

Keterangan:

$\Pi=$ Profit (keuntungan); $\mathrm{C}=$ Cost (biaya)

Semakin besar nilai MBCR, menunjukkan setiap tambahan input dalam formula pakan akan meningkatkan tambahan pendapatan sebesar nilai MBCR.

\section{HASIL DAN PEMBAHASAN}

\section{Konsumsi Bahan Kering, Protein Kasar dan Total Digestible Nutrient}

Rataan konsumsi bahan kering (BK) selama penelitian adalah 9,$29 ; 11,50 ; 9,80 ; 11,24$ $\mathrm{kg} / \mathrm{ekor} / \mathrm{hari}$ berturut-turut untuk untuk perlakuan A, B, C dan D seperti disajikan dalam Tabel 1. Hasil analisis statistik tingkat konsumsi tertinggi adalah perlakuan B tidak berbeda nyata dengan perlakuan $D$ dan perlakuan $\mathrm{C}$ tetapi berbeda nyata dengan perlakuan A sedangkan perlakuan A tidak berbeda nyata dengan perlakuan C. Dengan demikian tiga perlakuan $\mathrm{B}, \mathrm{C}$ dan $\mathrm{D}$ memberikan kontribusi yang sama. Berarti antara pemberian jerami segar ditambah dedak padi memberikan pengaruh yang sama terhadap konsumsi bahan kering. Hal ini mungkin disebabkan pakan pada perlakuan jerami segar dan dedak padi cukup disukai ternak. Demikian juga yang dikemukakan Wahyono et.al.(2003), bahwa palatabilitas berkaitan dengan faktor kebiasaan ternak dalam mengkonsumsi pakan, baik dalam keadaan kering, segar dan comboran.

Menurut Tillman et al.(1998), palatabilitas pakan dipengaruhi oleh beberapa faktor diantaranya rasa, bentuk dan bau dari pakan itu sendiri. Pada perlakuan tersebut pakan yang diberikan pada ternak berupa dedak padi dan konsentrat komersial masih dalam kondisi baik dan tidak ada efek ketengikan sehingga dapat meningkatkan konsumsi. Pemberian pakan dengan campuran konsentrat baik konsentrat komersial maupun dedak padi dapat meningkatkan daya cerna pakan secara keseluruhan, makin banyak konsentrat yang dapat dicerna, berarti arus pakan dalam saluran pencernaan menjadi lebih cepat, sehingga menyebabkan pengosongan rumen meningkat dan menimbulkan rasa lapar pada ternak akibatnya memungkinkan ternak untuk menambah konsumsi pakan. Sapi potong mampu mengkonsumsi bahan kering (BK) pakan sebanyak 3-3,50\% dari berat badan untuk setiap hari, sedangkan sapi potong berat $300 \mathrm{~kg}$ dengan PBBH $0,9 \mathrm{~kg}$ membutuhkan pakan dengan PK 10\% dan TDN 70\% (Tillman et al., 1998). 
Tabel 1. Rataan konsumsi zat makanan konsentrat/dedak padi dan jerami padi berdasarkan bahan kering

\begin{tabular}{cccc}
\hline \multirow{2}{*}{ Perlakuan pakan } & \multicolumn{3}{c}{ Konsumsi (kg/ekor/hari) } \\
\cline { 2 - 4 } & BK & PK & TDN \\
\hline A & $9,29 \mathrm{~b}$ & $0,76 \mathrm{c}$ & $2,54 \mathrm{a}$ \\
$\mathrm{B}$ & $11,50 \mathrm{a}$ & $1,067 \mathrm{~b}$ & $2,91 \mathrm{a}$ \\
$\mathrm{C}$ & $9,80 \mathrm{ab}$ & $1,026 \mathrm{~b}$ & $2,52 \mathrm{a}$ \\
$\mathrm{D}$ & $11,24 \mathrm{a}$ & $1,27 \mathrm{a}$ & $2,70 \mathrm{a}$ \\
\hline
\end{tabular}

Sumber : Data Primer diolah 2011

Keterangan : BK = Bahan Kering, PK = Protein Kasar, TDN = Total Digestible Nutrient

Menurut Parakkasi (1998), kemampuan ternak untuk mengkonsumsi bahan kering berkaitan dengan kapasitas fisik lambung dan kondisi saluran pencernaan. Tinggi rendahnya konsumsi pakan pada ternak ruminansia sangat dipengaruhi oleh faktor lingkungan dan kondisi ternak serta faktor pakan. Perbedaan jenis pakan yang menyusun ransum juga dapat menimbulkan perbedaan palatabilitas dan kandungan nutrisi yang pada akhirnya menyebabkan perbedaan jumlah pakan yang dikonsumsi oleh ternak (Suwignyo, 2004).

Faktor lain yang mempengaruhi konsumsi bahan kering (BK) pada ternak sapi potong yang digemukan menurut Siregar (1984) adalah besarnya tubuh, keaktifan dan kegiatan pertumbuhan atau produktivitas lainnya yaitu suhu dan kelembaban udara. Suhu udara yang tinggi menyebabkan kurangnya konsumsi pakan karena konsumsi air minum yang tinggi berakibat pada penurunan konsumsi energi. Konsumsi juga sangat dipengaruhi oleh palatabilitas yang tergantung pada beberapa hal yaitu penampilan dan bentuk makanan, bau, rasa, tekstur dan temperatur lingkungan.

Rataan konsumsi Protein Kasar (PK) yang menunjukkan bahwa tingkat konsumsi PK lebih banyak diperoleh dari perlakuan D, kemudian disusul perlakuan $\mathrm{B}$ dan $\mathrm{C}$ sedangkan yang paling rendah adalah perlakuan $\mathrm{A}$. Pakan yang diberikan pada perlakuan A berupa jerami segar dengan tingkat PK lebih rendah sehingga mengakibatkan konsumsi PK juga menjadi lebih rendah. Ini sesuai dengan pendapat Purbowati et al. (2007) yang menyatakan bahwa faktor yang mempengaruhi konsumsi PK adalah konsumsi BK dan kandungan PK pakan. Utomo (2001) menyatakan bahwa banyak sedikitnya konsumsi nutrisi tergantung pada jumlah BK pakan yang dikonsumsi ternak dan kandungan nutrisi dalam pakan yang diberikan.

Total Digestible Nutrient (TDN) yang diperoleh dari empat perlakuan menunjukkan hasil yang sama baik perlakuan A, B, C dan D. Perbedaan yang tidak nyata ini diduga karena kualitas pakan yang diberikan pada perlakuan hampir sama (terutama TDN), namun demikian kualitas pakan yang diberikan pada setiap perlakuan mempunyai kandungan protein kasar dan serat kasar yang berbeda. Pemberian konsentrat baik berupa konsentrat komersial maupun dedak padi pada ternak sapi potong yang digemukkan dapat meningkatkan daya cerna karena konsentrat mampu merangsang pertumbuhan mikroba rumen sehingga aktivitas pencernaan fermentatif lebih meningkat, yang pada gilirannya makin banyak bahan kering ransum yang dapat dicerna. Peningkatan daya cerna bahan kering ransum akibat bertambahnya jumlah pemberian konsentrat disebabkan karena konsentrat mempunyai nilai kecernaan yang tinggi dalam saluran pencernaan ternak ruminansia.

Komposisi nutrisi bahan pakan yang perlu menjadi pertimbangan dalam memproduksi pakan tambahan untuk ternak sapi potong adalah : $12 \%$ protein kasar, $60-75 \%$ karbohidrat, 3-5\% lemak kasar, serta mineral dan vitamin (Hendri et al., 2010). Berdasarkan hasil analisis bahan pakan menunjukkan bahwa dedak padi mempunyai kandungan protein lebih tinggi dibandingkan dengan konsentrat komersil masing-masing sebesar $13,98 \%$ dan $10,44 \%$. 
Tabel 2. Hasil analisis proksimat jerami padi segar, jerami padi fermentasi, konsentrat dan dedak padi

\begin{tabular}{lccrcccr}
\hline Uraian & \multicolumn{7}{c}{ Persentase } \\
\cline { 2 - 8 } & Air & Abu & \multicolumn{1}{c}{ PK } & \multicolumn{1}{c}{ SK } & LK & Ca & \multicolumn{1}{c}{ P } \\
\hline Jerami segar & 32,31 & 19,06 & 6,44 & 29,16 & 1,13 & 0,03 & 0,48 \\
Jerami fermentasi & 12,92 & 32,55 & 10,48 & 16,74 & 0,08 & 0,05 & 0,34 \\
Konsentrat & 15,32 & 19,04 & 10,44 & 9,93 & 7,00 & - & - \\
Dedak padi & 11,40 & 10,74 & 13,98 & 7,50 & 4,86 & - & - \\
\hline
\end{tabular}

Sumber : Laboratorium Pakan Ternak Cikole

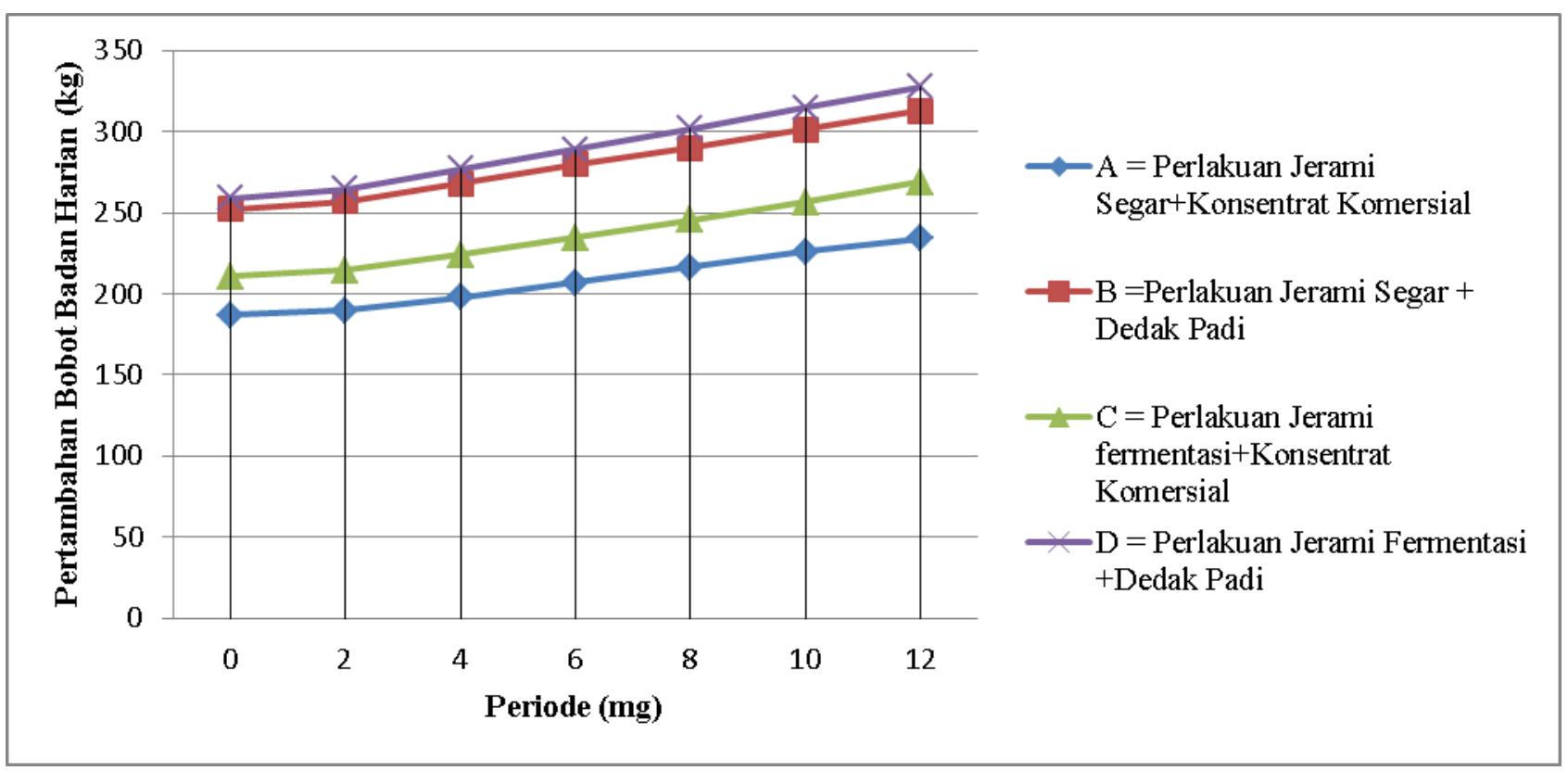

Grafik 1. Laju pertambahan bobot badan harian sapi potong selama 12 minggu

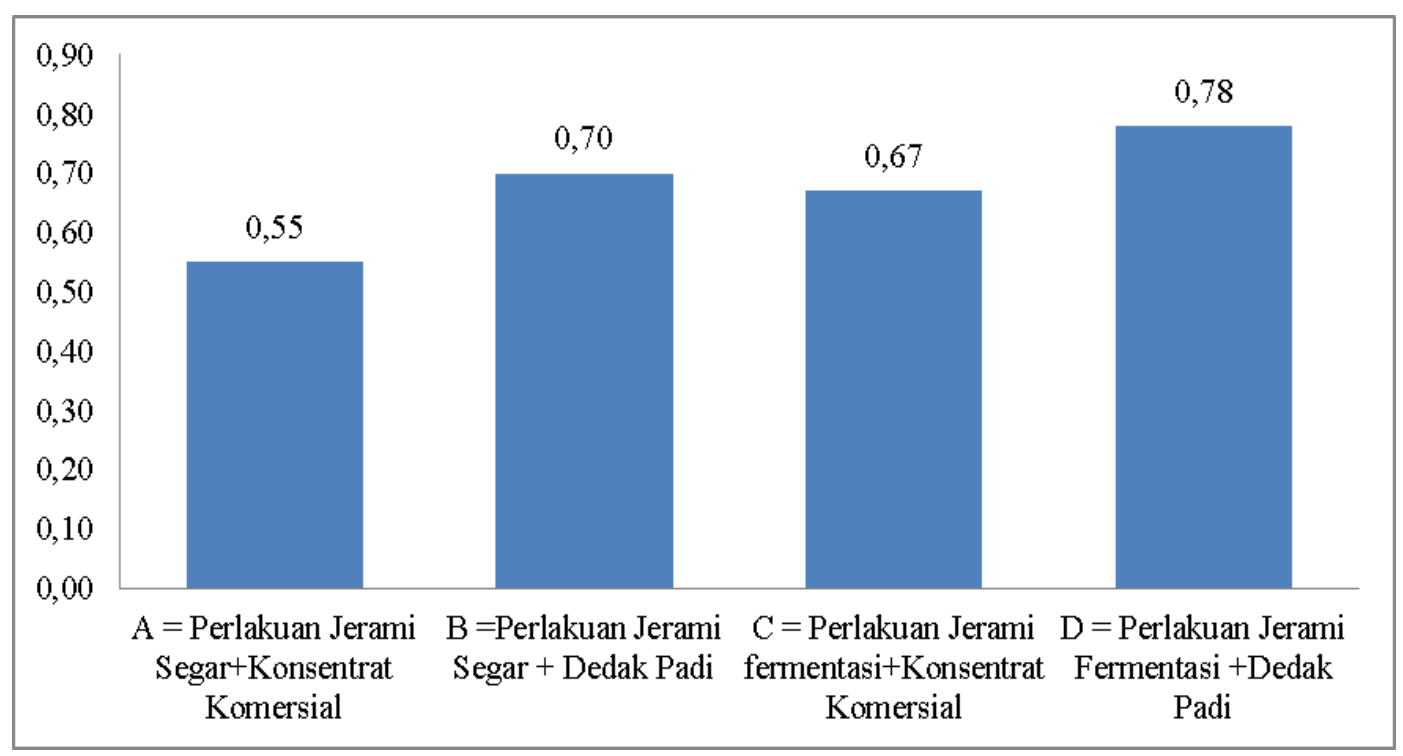

Grafik 2. Rata-rata pertambahan bobot badan harian ternak sapi potong 
Demikian pula dengan jerami fermentasi mengalami peningkatan dari $6,44 \%$ dengan proses pengolahan menjadi $10,48 \%$. Dengan memperhatikan kebutuhan nutrisi pada sapi potong pakan yang diberikan pada sapi perlakuan cukup memenuhi kebutuhan hidupnya. Untuk lebih jelasnya hasil analisa proksimat jerami padi segar, jerami fermentasi, konsentrat dan dedak disajikan pada Tabel 2. Pertambahan bobot badan merupakan satu refleksi dari akumulasi konsumsi, fermentasi, metabolisme dan penyerapan zat-zat makanan di dalam tubuh.

Pada usaha penggemukan sapi potong pertambahan bobot badan merupakan salah satu tujuan penting yang ingin dicapai. Bobot hidup akhir sangat dipengaruhi oleh jenis, jumlah dan mutu pakan yang diberikan. Jumlah dan kualitas pakan yang baik akan membantu ternak untuk tumbuh dan berproduksi (Wardani et al.,1997). Pertambahan bobot badan harian merupakan salah satu peubah yang dapat digunakan untuk menilai kualitas pakan ternak. Pertumbuhan ternak ditandai dengan peningkatan ukuran, bobot, dan adanya perkembangan. Pengukuran bobot badan berguna untuk penentuan tingkat konsumsi, efisiensi pakan dan harga (Parakkasi, 1999). Untuk lebih jelasnya pertambahan bobot badan harian ternak pada setiap perlakuan dapat dilihat pada Grafik 1.

Berdasarkan gambar grafik 1 menunjukkan bahwa sapi yang diberi jerami fermentasi ditambah dengan pemberian dedak padi sebanyak $3 \mathrm{~kg}$ (perlakuan D) menunjukkan bahwa pertambahan bobot badan harian (PBBH) lebih tinggi dibanding dengan ternak yang diberi perlakuan jerami segar dan konsentrat komersial (A). Perbedaan peningkatan PBBH diduga bahwa pakan yang diberikan dengan komposisi kimia yang cukup akan menghasilkan pertambahan bobot badan yang optimal. Hal ini sesuai dengan pendapat Tillman et al. (1998), faktor pakan sangat menentukan pertumbuhan, bila kualitasnya dan diberikan dalam jumlah yang cukup, maka pertumbuhannya akan menjadi cepat demikian pula sebaliknya. Rata-rata pertambahan bobot badan harian $(\mathrm{PBBH})$ untuk masing-masing perlakuan $\mathrm{D}, \mathrm{B}, \mathrm{C}$ dan $\mathrm{A}$ dapat dilihat pada Gambar 2. Hasil yang dicapai dalam pengkajian ini lebih tinggi dibanding dengan hasil pengamatan yang dilaporkan oleh Sugiharto (2003) dalam pengamatannya terhadap sapi potong PO pada 4-12 bulan PPBH mencapai 0,34-0,40 kg.

Demikian pula hasil pengamatan Purnomoadi et al. (2003) terhadap sapi PO yang berumur 10 bulan dengan pemberian pakan jerami fermentasi dan konsentrat yang mampu meningkatkan PBBH sebesar 0,24. Peningkatan pertambahan bobot badan harian $(\mathrm{PBBH})$ yang dihasilkan pada semua perlakuan menghasilkan pertambahan bobot badan di atas 0,55kg/ekor/hari dikarenakan semua sapi penggemukkan diberi pakan tambahan berupa konsentrat komersial dan dedak padi yang kandungan PK dari konsentrat komersial dan dedak padi di atas $10 \%$. Dengan pemberian pakan tambahan tersebut pertumbuhan ternak akan lebih baik dibandingkan dengan kebiasaan petani yang hanya diberikan hijauan pakan. Hal ini sesuai pendapat Soeparno (2005), yang menyatakan bahwa makin baik kualitas ransum yang dikonsumsi, maka akan diikuti dengan pertambahan bobot badan yang lebih tinggi dan makin efisien penggunaan ransumnya. Hal ini karena konsumsi protein dan energi yang lebih tinggi akan menghasilkan laju pertumbuhan yang lebih cepat.

\section{Kelayakan Usahaternak}

Pakan ternak merupakan komponen biaya produksi terbesar dalam suatu usaha peternakan. Oleh karena itu pengetahuan tentang pakan dan pemberiannya perlu mendapat perhatian.

Tabel 3. Biaya input variabel usahaternak perlakuan pemberian pakan (Ribu $\mathrm{Rp})$

\begin{tabular}{lcccc}
\hline \multirow{2}{*}{ Uraian } & \multicolumn{4}{c}{ Perlakuan } \\
\cline { 2 - 5 } & A & B & C & D \\
\hline Jerami Segar & 360 & 360 & - & - \\
$\begin{array}{l}\text { Jerami } \\
\text { Fermentasi }\end{array}$ & - & - & 297 & 297 \\
$\begin{array}{l}\text { Konsentrat } \\
\text { komersil } \\
\text { Dedak Padi }\end{array}$ & 432 & - & 432 & - \\
\hline
\end{tabular}


Tabel 4. Analisis usahaternak perlakuan pakan pada usaha penggemukan sapi potong

\begin{tabular}{|c|c|c|c|c|}
\hline Uraian & $\begin{array}{c}\text { Perlakuan } \\
\text { A }\end{array}$ & $\begin{array}{c}\text { Perlakuan } \\
\text { B }\end{array}$ & $\begin{array}{l}\text { Perlakuan } \\
\text { C }\end{array}$ & $\begin{array}{l}\text { Perlakuan } \\
\text { D }\end{array}$ \\
\hline \multicolumn{5}{|l|}{ A. Input Produksi (Rp) } \\
\hline \multicolumn{5}{|l|}{ Input Tetap : } \\
\hline Bakalan & 4.600 .000 & 5.300 .000 & 4.730 .000 & 5.580 .000 \\
\hline \multicolumn{5}{|l|}{ Input Variabel : } \\
\hline Hijauan Pakan Ternak & 360.000 & 360.000 & 297.000 & 297.000 \\
\hline Konsentrat & 432.000 & & 432.000 & \\
\hline Dedak & 0 & 360.000 & 0 & 360.000 \\
\hline Mineral & 9.000 & 9.000 & 9.000 & 9.000 \\
\hline B. Jumlah Input Variabel (Rp) & 801.000 & 729.000 & 738.000 & 666.000 \\
\hline \multicolumn{5}{|l|}{ C. Output Produksi (Rp) } \\
\hline $\begin{array}{l}\text { Pendapatan (PBBH X harga bobot hidup } \\
\text { ternak)/periode penggemukan }\end{array}$ & 1.350 .000 & 1.890 .000 & 1.809 .000 & 2.106 .000 \\
\hline D. Keuntungan (C-B) & 549.000 & 1.161 .000 & 1.080 .000 & 1.440 .000 \\
\hline E. B/C & 0,68 & 1,59 & 1,46 & 2,16 \\
\hline F. MBCR terhadap perlakuan A & & 0,91 & 0,78 & 1,48 \\
\hline
\end{tabular}

Ransum yang diberikan kepada ternak harus diformulasikan dengan baik dan semua bahan pakan yang dipergunakan dalam menyusun ransum harus mendukung produksi yang optimal dan efisien sehingga usaha yang dilakukan dapat menjadi lebih ekonomis. Untuk mengetahui perlakuan pemberian pakan yang lebih ekonomis dilakukan uji analisis losses and gain dengan membandingkan perlakuan (A) dengan perlakuan B, C dan D yang diperoleh dari nilai marginal benefit cost ratio (MBCR).

Berdasarkan Tabel 3 dapat diketahui dengan perlakuan pemberian hijauan jerami fermentasi dapat menghemat biaya pengadaan pakan, hal ini disebabkan dengan pemberian hijauan jerami fermentasi seluruh bagian pakan dapat dikonsumsi oleh ternak, sedangkan dengan pemberian jerami segar sebagian besar jerami terbuang karena sulit dicerna. Hal ini dapat dilihat dari banyaknya jerami segar yang terbuang di sekitar tempat pemberian pakan. Oleh karena itu pemberian jerami fermentasi selain menghemat konsumsi jerami juga menghemat waktu dalam pengadaan pakan.

Pemberian dedak padi sebagai pengganti konsentrat komersil memberikan tambahan keuntungan karena harga dedak yang relatif lebih murah daripada konsentrat komersil, sedangkan kandungan nilai protein kasarnya lebih tinggi (Tabel 2) sehingga memberikan dua keuntungan.

Berdasarkan tabel 4 dapat diperoleh nilai MBCR 3 perlakuan (B, C dan D) terhadap cara petani (A) diperoleh nilai terbesar pada perlakuan $\mathrm{D}$, yaitu pemberian jerami fermentasi dan dedak padi. Hal ini disebabkan selain lebih efisiennya biaya pakan juga diperoleh pertambahan berat badan harian yang lebih besar.

\section{KESIMPULAN}

1. Pemanfaatan dedak padi dan jerami fermentasi memberikan pertambahan bobot badan tertinggi dan secara ekonomi memberikan keuntungan tertinggi.

2. Pemanfaatan limbah pertanian jerami padi dan dedak padi diperlukan dalam program penggemukan sapi di Jawa Barat.

\section{DAFTAR PUSTAKA}

Basuni, R. et al. 2010.Model sistem integrasi padi sapi potong di lahan sawah. Forum Pasca Sarjana, Juli 2010, Vol. 33 : 177190 
BPS,. 2012. Jawa Barat dalam angka., BPS Propinsi Jawa Barat

Gordeyase, I.K.M., R. Hartanto, dan W.D. Pratiwi. 2006. Proyeksi daya dukung pakan limbah tanaman pangan untuk ternak ruminansia di Jawa Tengah. J. Indon. Trop. Anim.Agric. 32(4): 285-292.

Hendri, Y., P.Yufdy dan Azwir, K. 2010. Beternak Sapi dengan Pakan Lokal. Balai Pengkajian Teknologi Pertanian Sumatera Barat. Hal.51.

Kariyasa, K. 2005. Sistem integrasi tanaman ternak dalam perspektif reorientasi kebijakan subsidi pupuk dan peningkatan pendapatan petani. Jurnal Analisis Kebijakan Pertanian 3(1): 68-80.

Malian, AH. 2004. Analisis ekonomi usahatani dan kelayakan finansial teknologi pada skala pengkajian. Makalah disajikan dalam Pelatihan Analisis Finansial dan Ekonomi bagi Pengembangan Sistem Usahatani Agribisnis Wilayah. Bogor

Parakkasi, A. 1999. Ilmu nutrisi dan makanan ternak ruminan. Penerbit Universitas Indonesia, Jakarta.

Purbowati, E., C.I. Sutrisno, E. Baliarti, S.P.S. Budhi, dan W. Lestariana. 2007. Pengaruh pakan komplit dengan kadar protein dan energi yang berbeda pada penggemukan domba lokal jantan secara feedlot terhadap konversi pakan.

Siregal, 1996. Penggemukan sapi potong. Penebar Swadaya, Jakarta

Swastika, D.K.S. 2004. Beberapa teknis analisis dalam penelitian dan pengkajian teknologi pertanian. Jurnal Pengkajian dan Pengembangan Teknologi Pertanian. $10(2)$
Soeparno, 2005. Ilmu dan teknologi daging. Cet. Ke IV. Gajah Mada University Press. Yogyakarta.

Subandriyo et al. 2000. Pendugaan kualitas bahan pakan untuk teroak ruminansia. Fakultas Peternakan Institut Pertanian Bogor. http ://www.fapet-ipb.ac.id/files /edu Diakses 28 Agustus 2012

Suryana. 2007. Pengembangan integrasi ternak ruminansia pada perkebunan kelapa sawit. Jurnal Penelitian dan Pengembangan Pertanian 26(1): 35-40.

Suwignyo, B. 2004. Sektor peternakan komoditi utama penggerak perekonomian. Cyber News. Suara Merdeka. Yogyakarta

Suryana. 2007. Pengembangan integrasi ternak ruminansia pada perkebunan kelapa sawit. Jurnal Penelitian dan Pengembangan Pertanian 26(1): 35-40.

Syamsu, J.A.2006. Kajian penggunaan starter mikroba dalam fermentasi jerami padi sebagai sumber pakan pada peternakan rakyat di Sulawesi Tenggara. Disampaikan dalam Seminar Nasional Bioteknologi. Puslit Bioteknologi LIPI, Bogor

Tillman, A.D., H. Hartadi, S. Reksohadiprodjo, S. Prawirokusumo dan S. Lebdosoekojo. 1998. Ilmu makanan ternak dasar. Cetakan Keempat. Gadjah Mada University Press, Yogyakarta.

Utomo, R. 2001. Penggunaan jerami padi sebagai pakan basal : suplementasi sumber energi dan protein terhadap transit partikel pakan, sintesis protein mikroba, kecernaan dan kinerja sapi potong. Disertasi. Program Pascasarjana. Universitas Gadjah Mada. Yogyakarta. 